\title{
GENDER IN TRANSLATING LESBIANISM IN THE SECOND SEX
}

\author{
Zhongli Yu \\ University of Manchester, Nanjing Agricultural University
}

\begin{abstract}
Drawing on three Chinese translations of the lesbian chapter in Simone de Beauvoir's The Second Sex, this paper examines at the micro level how the discussions on lesbianism in the work are translated and what role gender identity plays in the process of translation. Lesbianism has played an important part in feminism. However, homosexuality is still regarded as unacceptable to most Chinese people. Thus, an examination of translations of lesbianism in The Second Sex might be especially revealing in terms of representation of Western feminism. The comparison reveals that there are obvious differences between the translations by the female translators and the male translators. The differences mainly lie in translation strategies, understanding of lesbianism, and attitudes towards lesbianism. In these differences, gender plays a key role.
\end{abstract}

\section{Résumé}

En s'appuyant sur trois traductions chinoises du chapitre "lesbienne" dans Le Deuxième Sexe de Simone de Beauvoir, le présent article examine au niveau microscopique comment les débats sur le lesbianisme dans l'oeuvre sont traduits et comment l'identité du genre influence le processus de la traduction. Lesbianisme a joué un rôle important dans le féminisme. Toutefois, l'homosexualité est toujours considérée comme inacceptable pour la plupart des Chinois. Ainsi, un examen des traductions du lesbianisme dans Le Deuxième Sexe pourrait être particulièrement révélateur en termes de représentation du féminisme occidental. La comparaison révèle qu'il existe des différences évidentes entre les traductions par des femmes et par des hommes. Les différences se situent principalement dans les stratégies de traduction, la compréhension du lesbianisme et les attitudes envers le lesbianisme. Dans ces différences, le genre joue un rôle majeur. 
Keywords: Gender. Translating. Beauvoir. Lesbianism. Feminism.

Mots clés: Genre. En traduisant. Beauvoir. Lesbianisme. Féminisme. 
Gender and sexuality are the emphasis in The Second Sex (1949), a feminist classic by French feminist and existentialist writer Simone de Beauvoir (19081986). Beauvoir takes "the intimate, the affective, and the sexual" as "the heart of lived experience, the centre of philosophical enquiry, and the core of human condition" (Hawthorne 2000: 4-5). This has brought her quite some criticism, even attacks. Some feminist philosophers have criticised The Second Sex as heterosexist, masculinist, and Sartrean (Simons 1999: 115). However, Beauvoir's life has been found to include the love of both women and men (Simons 1999: 143). Inevitably, Beauvoir has been regarded as a lesbian although she never said she was (Beauvoir 1975: 197, Altman 2007: 211). Beauvoir takes lesbianism as one of the ways to overcome women's erotic passivity (Fuchs 1980: 310). Hence in Book II, Beauvoir devotes a special chapter entitled "The Lesbian" to a discussion of lesbian formation. Actually, lesbian experience and feeling are not confined to this chapter. Lesbianism occurs from the first chapter "Childhood", through "The Young Girl", to "Sexual Initiation". Her analysis to a nicety of lesbian formation to some degrees reflects her understanding of lesbianism from her own intimate relations with some female friends.

Drawing on three Chinese translations of the lesbian chapter in The Second Sex, this paper examines at the micro level how the discussions on lesbianism in the work are translated and what role gender identity plays in the process of translation. Lesbianism has played an important part in feminism. However, homosexuality is still regarded as unacceptable to most Chinese people. Thus, an examination of translations of lesbianism in The Second Sex might be especially revealing in terms of the representation of Western feminism.

\section{Gender and sexuality in translation studies}

Before a discussion of lesbianism in the Chinese translations of The Second Sex, a brief review of gender and sexuality in translation studies is necessary to contextualize the present study. Gender refers to "the cultural trappings that accompany biological sexual difference" and "the linguistic representations of the trappings", and sexuality to "the linguistic representations of 
sexual practices" (Flotow 2009: 122). Gender entered into translation studies in the 1980s, and sexuality is an emerging trend in the field. Although closely-related, gender and sexuality have been treated separately in translation studies (Flotow 2009: 122). Hence, in what follows, gender and sexuality in translation studies are reviewed separately.

\subsection{Gender in translation studies}

Gender became an important issue in translation studies from the 1980s. Issues such as cooperation between the translator and the author to achieve a feminist translation (Diaz-Diocaretz 1985), translating French feminism (Porter 1987), gender in the representation of translation (Chamberlain 1988) and translating sexist language (Bird 1988) were discussed. In this period, the term "feminist translation" was coined as a result of a wide discussion on the translation of women's writing in Euro-America, especially in Canada.

In the 1990s, there appeared a proliferation of gender-related translation studies from various perspectives, such as the connections between feminism and translation in the context of French translation (Godard 1990, LotbinièreHarwood 1991), French feminist theory in translation (Freiwald 1991), feminist translation strategies (Flotow 1991 \& 1997a, Massardier-Kenney 1997, Maier 1998), the feminist translator's delight in translation (Bassnett 1992), the oppositional voices of women as writers and translators of literature in the English Renaissance (Krontiris 1992), contradictions in feminist translation (Arrojo 1994, 1995), women as translators and researchers in history (Robinson 1995), gender in/and literary translation (Maier and MassardierKenney 1996), translating women's fiction (Maier 1998), and gender identity in the text/reader transaction (Henitiuk 1999) or in representation of gender in translation (Hartman 1999).

It is in the 1990s that two seminal books were published: Gender in Translation: Cultural Identity and the Politics of Transmission (1996), by Sherry Simon, and Translation and Gender: Translating in the "Era of Feminism" (1997), by Luise von Flotow. In her book, Simon foregrounds "the encounter between gender and translation studies" and "position translation within cultural studies" (Simon 1996: viii-ix). Flotow is someone who has worked steadily on the subject matter from 1991 to the present (see Flotow 1991, 1994, 1995a\&b, 1996a\&b, 1997a\&b, 1998, 2002, 2005, 2006). In her 1997 book, she gives a systematic discussion on feminist translation based on her research since 1991 (see Flotow 1997a). These two books complement each other, forming a full and clear account of the emergence, development and influence of 
feminist translation up to the time the books were published. They mark the formation of feminist translation theory.

The twenty-first century has witnessed further development in genderrelated translation studies, which have shown a broader scope than before. While some previous topics continue to fare well, such as the influence of gender identity or of feminism in translation (Hellerstein 2000, Andone 2002, Hamerlain 2005), women's role in translation in history (Agorni 2005), and feminist translation strategies (Wallmach 2006), new perspectives are emerging, such as those presented in Gender, Sex and Translation: The Manipulation of Identities, another important book in gender-related translation studies, edited by José Santaemilia (2005c). The book contains research on translation from or into languages other than English or European languages (Smith 2005), which was hardly seen in publications in the twentieth century. It goes beyond the belles lettres, the major subject in early discussions, to include research on translations of more genres, such as translation of spoken language in films (Baumgarten 2005) and in the medical sphere (Weber, Singy and Guex 2005). It also includes research from perspectives not noticed before, such as gender issues in nationalist discourse (Ríos and Palacios 2005) and issues in teaching gender and translation (Susam-Sarajeva 2005). Furthermore, it contains research incorporating recent developments in feminism (Martín 2005). As feminist translation emerged in the second wave of feminism, feminist concepts reflected in feminist translation and its studies, such as écriture feminine (Cixous 1975), have sometimes seemed outdated in the era of the third wave of feminism. The theory of performativity gradually takes more currency in understanding the notion of gender (Butler 1999). All these signify that there are many more areas to be explored in gender and translation.

The marriage of gender and translation in the West were noticed by Chinese scholars in the late 1990s, such as Canadian feminist translation studies and its contribution to translation studies (Han Jiaming 1996), Western feminist thinking of translation (Liao Qiyi 1998), and the influence of Western feminism in translation studies (Xie Tianzhen 1999). Meanwhile, genderrelated translation studies started to appear in China, covering the distortion of Western women's image in translated novels in the late Qing dynasty (Kong Huiyi, also known as Eva Hung, 1998), and the great gender imbalance in Chinese translators-female translators making up only $7.5 \%$ of the total number of Chinese translators included in Zhongguo fanyijia cidian [Dictionary of Chinese Translators] (Mu Lei 1999).

The twenty-first century has witnessed an upsurge of interest in gender issues in translation among Chinese researchers. In 2001, the first chapter 
of Simon's Gender in Translation was translated into Chinese with the title of "Fanyi lilun zhong de xingbie" [Gender in Translation Theory] and included in the book Yuyan yu fanyi de zhengzhi [Language and the Politics of Translation] edited by Xu Baoqiang and Yuan Wei (2001: 309-357). In 2004, Flotow's Translation and Gender was reprinted in China in a local English edition. These two works are two major references for those who do gender-related translation studies in China.

Also in 2004, Chinese Translators Journal (No. 4), the only top-ranking academic journal in translation studies in China, published four papers on feminism and translation and feminist translation theory, respectively by Liu Junping, Jiang Xiaohua, Xu Lai and Zhang Jinghua. This is the first time this journal published several papers on a single theme in one volume. These papers form a kind of detailed introduction, translation and/or interpretation of Translation and Gender. In fact, well before this point in the same year, Chinese Translators Journal (No. 2) had published an article on ten years of Canadian translation theory in which Canadian feminist translation theory, especially the research by Simon and Flotow, was introduced (Chen Lin 2004). These papers have helped spread the knowledge of and the circulation of Translation and Gender in China, since it is produced in English without Chinese translation and it is much easier for Chinese readers to read and understand the papers in Chinese.

Since then, increased interest has been seen right up to the present. CNKI, iLib and VIP databases in China show that by November 2008, 187 published journal articles had dealt with gender-related issues. Gender issues in translation entered into MA dissertations from 2004. According to CNKI, by November 2008, fifty MA dissertations had discussed such issues. Students are usually influenced by their supervisors in choosing dissertation topics. $\mathrm{Mu}$ Lei has a strong interest in female translators, women writers and their works, and Western and Chinese feminism (see Mu Lei 2002, 2003). Several M.A. students of hers have chosen to work on gender issues in translation. Some of the studies have formed a book Gender Perspective in Translation Studies (Mu Lei et al. 2008), the first book dealing with gender and feminism in translation in China.

\subsection{Sexuality in translation studies}

Sexuality came to be an analytical category in translation studies recently, often related to censorship on sexuality (Flotow 2009), such as Flotow 2000, Linder 2004 and Santaemilia 2008b. Studies on sexuality in translation started to appear from the late 1990s, such as Larkosh 1996, and more appeared since 
2000. Studies in the twenty first century have covered several aspects, such as the English translation of sex in Beauvoir's works (including the "Sexual Initiation" chapter in The Second Sex) (Flotow 2000), sexual imagery in Anglo-American translations of the Comedy (Crisafulli 2001), sexual language and gender in translation (Santaemilia $2005 \mathrm{a} \& b, 2006,2008 \mathrm{a} \& \mathrm{~b}$ ), the roles of self-translation in the definition and development of sexual identity (Guldin 2007), and the relationship between translation and sexuality, especially the forms of sexuality often considered to be beyond the limits of the normative (Larkosh 2007). In the existent research, homosexuality tends to become a new analytical category and much has yet to be explored. A few studies concerning gay in/and translation have appeared, such as a gay translator making gay visible in translating a gay text (Keenaghan 1998), translating gay texts and gay identity in translation (Harvey 1998, $2000 \& 2003$ ), and sexual identity in translating gay theatre (Kinloch 2007). Unfortunately, studies concerning lesbian(ism) in/and translation can hardly be found. This paper is an attempt to break the ice.

In fact, sexuality in translation is still more or less a taboo topic in China and has little chance to get published in Chinese. In 2006, I asked an editor of a key journal in translation studies in China if the journal would accept a paper on translations of The Vagina Monologues (which is now part of my $\mathrm{PhD}$ dissertation). I was advised not to work on it as they would not publish papers concerning politics and sexuality. Therefore, research on sexuality in translation in China has been rare, not to mention on homosexuality, which is unacceptable to most Chinese people. This study sounds bold in the Chinese context.

\section{The Second Sex and the Chinese translations}

The Second Sex is a two-volume study of women, in which Beauvoir discusses the formation of women, women's body and eroticism at length, making a scholarly and passionate plea for the abolition of the myth of the eternal feminine. Since its publication, The Second Sex has been translated into many different languages and read worldwide. Interest in it continues unabated today.

The Second Sex came to China when China began to open up to the outside world. In the late 1970s, a Taiwan translation of The Second Sex (Book II) was circulating among female intellectuals in Beijing and some other big cities (Dai Jinhua 2007: 36-37). In 1983, the first introduction to The Second Sex appeared in the preface of Meiguo nvzuojia duanpian xiaoshuo xuan [A Selection of Short Stories by American Women Writers], edited by Zhu Hong (Luo Ting and Wang Fang 2004: 125). In the book, Zhu Hong introduced Western 
feminism, which thrilled many sensitive women (Lin Shuming 1999: 128). Three years later, the 1986 Chinese translation of The Second Sex, for the first time, systematically brought feminism into China and pushed the development of feminism in China (Huang Lin 2006 \& 2009).

From 1986 up to now, there have been seven Chinese translations of The Second Sex, partial or complete, all based on the first English translation published in 1952 by Howard M. Parshley (1884-1953):

1) the 1986 translation of Book II Women's Life of Today, a reprint from a Taiwan version by Sang Zhuying and Nan Shan;

2) the 1988 abridged translation of Book II by Wang Youqin and Qiu Xichun et al., renamed Nvren shi shenme [What is Woman], with several sections and parts deleted: "The Lesbian" in Part IV, "Prostitutes and Hetairas" in Part V, Part VI "Justifications" and Part VII "Towards Liberation";

3) the 1988 translation of Book I Facts and Myths by Xiao Yi and Zhang Yali et al., renamed as Nvxing de mimi [Female Secrets];

4) the 1998 translation by Tao Tiezhu, the first Chinese translation of the whole book;

5) the 2004 abridged translation by Li Qiang, with a short section "The Mystic" in Part VI "Justifications" cut;

6) the two 2009 translations by Tang Yi and Shu Xiaofei, respectively.

Besides these seven translations, the first Chinese translation from the French original is expected to come out soon. It was announced to be published in the summer of 2009 by Shanghai Translation Publishing House to celebrate the Centennial of Simone de Beauvoir's birth (see Huang Hong 2009; Shen Ke 2009). For the same reason, a new English translation by Constance Borde and Sheila Malovany-Chevallier was published in the end of 2009.

The English source text of the Chinese translations has been much criticized, fairly or unfairly, by some Beauvoir scholars for the omissions and mistranslations (see Simons 1983, Fallaize 2002, and Moi 2002). The defective English translation inevitably puts the credibility of all the Chinese translations under suspicion. However, it seems that the controversy over the English translation has received little attention in China, not only in the fields of Philosophy and gender/women studies, but also in translation studies. The Chinese translations have been read and discussed as if they had been produced in Chinese. Criticisms of the English translation of The Second Sex appeared from the 1980s, mainly in America. However, few discussions of Chinese translations of such an influential work can be found, except a few 
references to the problems in the English translation for justifying the Chinese new translation from the French (see Chen Huan 2004, Liu Kunya 2009, Shen Ke and $\mathrm{Xu}$ Jun 2009). This is not surprising in view of the fact that it took over 30 years for criticisms of Parshley's English translation to appear. This research might attract more attention to the Chinese translations of this feminist classic.

\section{Lesbianism in the Chinese translations}

This section is a close reading of the three Chinese translations of the lesbian chapter by Sang Zhuying and Nan Shan (1986), Tao Tiezhu (1998) and Li Qiang (2004). In the abridged translation by Li Qiang, a large proportion of descriptions, analysis and illustrations of women's life experience are cut. Hence, most of the lesbian chapter is cut out with only six pages left, while the lesbian chapter is twenty-two pages long in the other two translations.

The two 1988 translations are not examined here because the translation by Xiao Yi and Zhang Yali et al. is a translation of Book I which does not contain the lesbian chapter, and the lesbian chapter is cut in the translation by Wang Youqin and Qiu Xichun et al.. The two 2009 translations are not examined here either because they seem to be identical and most importantly, although published under the names of different translators and in different months by different publishers, both seem to be reprintings of the 2004 translation by Li Qiang with some further chapters deleted. Such reprintings to some extent reveal the popularity of The Second Sex in China, but are not useful in the context of the present study.

In the examples analysed, ST stands for the source text of 1993, S/N for the translation by Sang Zhuying and Nan Shan, Tao for the translation by Tao Tiezhu, and Li for the translation by Li Qiang. The page number is included in brackets after each example. The translations are presented in chronological order and each Chinese translation is followed by its back translation in English in square brackets.

Sang Zhuying and Nan Shan are female translators, Tao Tiezhu and $\mathrm{Li}$ Qiang are male translators. A comparative examination of the three translations reveals clear differences due to the gender identities of the translators. The differences mainly lie in translation strategies, understanding of lesbianism, and attitudes towards lesbianism. Of course, these three categories are a rough division. They overlap and interconnect to a great extent. Therefore, it is hard to find a clear-cut distinction between them. 


\subsection{Translation strategies}

The three translations exhibit obvious differences in the translation strategies adopted by the female and male translators. For example,

(1) ST: Only the lesbian could have as rich a libido as that of the male, and she would therefore represent a 'superior' feminine type. (427)

$\mathrm{S} / \mathrm{N}$ ：唯有女同性恋才能有男性一般的强盛性欲, 如此她可代表女性 之间的 “优越型”。(176)

[Only a lesbian can have the same strong sexual desire as a man does, thus she may represent the 'superior' type among women.]

Tao: 唯有女性同性恋才可以有和男人一样丰富的利比多, 因而她将 代表一种 “优越的” 女性类型。（464）

[Only a lesbian can have the same rich libido as a man does, hence she will represent a 'superior' type of women.]

Li: (cut) (172)

The word 'libido' in the source text refers to 'sexual desire', which remains the same in the translation by $\mathrm{S} / \mathrm{N}$. Tao transliterates it, retaining its pronunciation, which is understandable to some Chinese readers familiar with Freudian psychology but not to general readers. It is true that 'libido' is mostly transliterated in Chinese as in the Chinese translations of Freud's works (see Gao Juefu 1984/2004: 2; Zhou Quan, Yan Zesheng and Zhao Qianghai 2000/2007: 4) and in some English-Chinese and Chinese-English dictionaries (see Lu Gusun 1989/2003: 1885; Wu Guanghua 1993/2002: 1027; Wu Guanghua 1998: 1347; Ge Chaungui, Lu Gusun and Xue Shiqi et al. 2000/2002: 745; Thompson and Chen Kai 2003: 1169). However, the meaning is not widely known to most general readers. Even if some readers have heard of this pronunciation, they may not necessarily know the exact meaning and may not immediately understand the translation. This may interrupt the reading flow. The translation by the female translator makes unobstructed reading for both the general reader and the academic reader.

In addition, 'would' in the source text refers to a possibility rather than the past tense of 'will'. S/N translates it into '可' [may] which retains the meaning of possibility although the Chinese character '可' [may] does not have inflections indicating tense. Tao misunderstands 'would' as the past tense of 'will' and mistranslates it into '将' [will], turning a possibility into a fact. This type of problem is further discussed in the next section.

Besides transliteration, Tao even adopts zero-translation with Chinese annotation in square brackets when the English text contains French words. For example, 
(2) ST: the 'garçon manqué' stubbornly retains her boyishness. (431)

$\mathrm{S} / \mathrm{N}$ : 这位_“顽皮姑娘”就固执地保留她的男孩子气。（180）

[this "tomboy" stubbornly retains her boyishness.]

Tao: “gracon [sic] manqué”[男孩子气的女孩子] 就会顽固保持她的男 孩子气质。(468)

["gracon [sic] manqué" [boyish girll will stubbornly retain her boyishness.]

Li: (cut) (173)

(3) ST: Because the partners are homologous, basically alike, all kinds of combinations, transpositions, exchanges, comédies are possible. (441)

$\mathrm{S} / \mathrm{N}$ : 由于双方是对等的, 基本上是相象的, 所以各种组合、转移、 交替、喜剧, 都是可能的。(190-1)

[Because both sides are equal, basically alike, all kinds of combinations, transpositions, alternations, $\underline{\text { comedies }}$ are possible.]

Tao: 由于两个性伙伴是对等的、基本相似的, 种种结合、易位、交 替和comédies [可笑的举动]都可能发生。(478)

[Because the two sexual partners are equal, basically alike, all kinds of combinations, transpositions, alternations, comédies [funny behaviour] are possible.]

Li: (cut) (173)

In these two examples, $\mathrm{S} / \mathrm{N}$ translate the French terms into Chinese, making the meaning clear to the target reader. Tao keeps the French terms and explains the meaning in Chinese in square brackets. The French terms in the English source text may not appear very strange and cause reading difficulty to English readers due to the similarities between the two languages. A good example is 'comedies' and 'comedy'. In addition, 'comedy' has different implications to and produces different associations among the Chinese and the Euro-American readers. This is an interesting topic but not the focus in this study and is not discussed here. In the Chinese context, they may make some sense to some bilingual readers, making them aware of the source language but probably become a burden to many general readers. These examples show the word-for-word translation strategy by Tao.

\subsection{Understanding of lesbianism}

Tao's rigid word-for-word translation strategy sometimes makes his translation ambiguous or even wrong because he often makes a wrong choice from standard dictionary definitions (such as translating 'would' into 'will' in 
Example 1), reflecting his (mis)understanding of the source text. Examples 4-6 reflect unreliable interpretations of lesbianism by the male translators.

(4) ST: certain women decline passivity, whereas others choose feminine arms in which to abandon themselves passively. (429)

$\mathrm{S} / \mathrm{N}$ : 某些女人拒绝被动, 另一些女人则选择女性之怀抱来被动地放 纵自己。(178)

[Some women refuse passivity, while others choose female arms in which to indulge themselves passively.]

Tao：有些女人拒绝被动，而另一些女人则愿意用女性的武器被动地 放纵自己。(466)

[Some women refuse passivity, while others are willing to use female weapons in which to indulge themselves passively.]

Li：有的女性拒绝被动性，而另外一些女性则甘愿用女人的本钱来被 动地放纵自己。(173)

[Some women refuse passivity, while others are willing to use female assets in which to indulge themselves passively.]

Here, 'feminine arms' refers to lesbian intimate or sexual relations and bodily contact. Tao mistranslates it as 'female weapons'. This not only reflects his misunderstanding of the source text, but also misleads the reader. 'Weapons' is one of the dictionary meanings of 'arms', but 'female weapons' in Chinese usually refers to female sexual attraction that may be exercised to men for some purposes. Obviously, the source text does not mean this. Li translates into 'female assets', another phrase to express female sexual attraction to men. Both are closely related to heterosexuality. This interesting similarity indicates male perspective in their (mis)understanding lesbianism.

(5) ST: most little girls feel the same sense of outrage and the same desperation when they learn that the chance conformation of their bodies renders their tastes and aspirations blameworthy. (430)

$\mathrm{S} / \mathrm{N}$ : 多年 [sic]的小女孩, 在得知她们生来之性别使她们的爱好与抱 负变得不正当时，都会感到同样的愤怒与绝望。（179）

[Little girls of many years [sic] will feel the same anger and despair when they know that their sex by birth makes their hobbies and ambitions improper.]

Tao: 许多小女孩当认识到对她们身体的偶然适应将使她们的爱好与 抱负变得有罪时，也会同样感到愤怒和绝望。（468）

[Many little girls will also feel the same anger and despair when they are aware that chance adaptation to their bodies will make their hobbies and ambitions guilty.]

Li: (cut) (173) 
By 'the chance conformation of their bodies', Beauvoir intends to explain that it is merely an incident that one is born into the female sex; it is the patriarchal society that relegates women to the inferior sex and there is nothing wrong with their biological sex. S/N translate it into 'their sex at birth', conveying the sense of the source text while Tao translates into 'chance adaptation to their bodies', a word-for-word translation, which makes little sense in itself, showing that Tao does not understand the source text. Incidentally, '多 年' [many years] in S/N's translation should be a typographical error of '多数' [majority or many].

(6) ST: Though she can employ artificial means for the deflowering and possessing her loved one, she is none the less a castrate [...]. She is unfulfilled as a woman, impotent as a man, [...]. (434)

$\mathrm{S} / \mathrm{N}$ : 但虽然她能运用人造工具﨎入而占有她的爱人, 她到底缺乏男 性之性能, [...]。就女人身份而言, 她得不到满足与报偿, 就男人身 份而言, 她没有性能力, [...]。（183）

[But although she can use artificial tools to penetrate and possess her lover, she after all lacks masculine sexual function. [...]. As a woman, she gains no satisfaction and reward; and as a man, she has no sexual capacity. [...].]

Tao: 虽然她能够以人为方式夺取她爱人的贞操并将她占有, 但她仍 然是个阉人, $[\ldots]$ 。她作为一个女人是未实现的, 作为一个男人又是 无性能力的, [...]。(471)

[Although she can dispossess the virtue of her lover and possess her in an artificial way, she is still a castrated person. [...]. As a woman, she is unrealized, and as a man, she has no sexual capacity. [...].]

Li: 然而就算她可以用人为手段夺走她情人的贞操而占有她, 也改变 不了她是个阉人的事实, [...]。她不能以一个女人的身份也不能真正 作为一个男人而实现其性行为, $[\ldots]$ 。 (175)

[However even if she can dispossess the virtue of her lover and possess her in an artificial way, she cannot change the fact that she is a castrated person. [...]. She cannot carry out her sexual act either as a woman or as a real man. [...].]

This example tells the sexual embarrassment in lesbianism due to the lack of a male sexual organ. As a result, a lesbian can neither gain sexual satisfaction from homosexual love as a woman, nor can she satisfy her loved one as a man. 'Unfulfilled' in the source text actually means sexual unsatisfaction. The translation by the female translator reflects this sense while Tao translates it literally into 'unrealized' which makes little sense in the Chinese sentence. Li's translation makes sense in Chinese but does not convey the exact source meaning. 'Carry out her sexual act' refers to the action, the process, while 'fulfill' refers to the result. 
Still in this example, 'employ artificial means' tells how a masculine lesbian makes love with her lover. 'Means' has different meanings. It can refer to either a method or an instrument used to obtain a result or achieve an end. $\mathrm{S} / \mathrm{N}$ translate it into 'use artificial tools', which makes the meaning of the source text very explicit while Tao and Li all translate it into 'in an artificial way', a term of ambiguity. More such specious or wrong expressions in their translations of the lesbian chapter can be found, especially in Tao's translation [see Tao/Li 468/173 (cut), 474/175 (example 8), 475/175 (cut), 477/176 (example 10), and 482/176 (cut)].

These various translation problems, seldom found in the work of the female translators, may be due to language incompetence. However, gender identity may play a role as well. As a heterosexual man, it may be hard for the male translators to understand lesbian relations and sexuality. The following two examples show this.

(7) ST: One patient said to Dalbiez: 'If I only had something to penetrate with, it would be better.' Another wished that her breasts were rigid. (434)

$\mathrm{S} / \mathrm{N}$ : 一个病人告诉达比也兹（Dabiez）：“只要我有什么可以翟入 的，情形就会好得多。”另一病人希望她的奶是平的。（183）

[A patient told Dalbiez: "If I had something to penetrate with, the situation would be better." Another wished that her breasts were flat.]

Tao: 有一位病人对达尔比兹说: “要是只有我才有能用来插入的某 物, 那就好了。”另一个病人则希望她的乳房是坚挺的。（471）

[A patient said to Dalbiez: "If I were the only one who had something to penetrate with, it would be good." Another wished that her breasts were firm.]

Li：一位病人对代尔比茨（Dalbiez）承认：“要是只有我才有用来 插入的某个器官该多好。”而另外的一个病人则渴望自己的乳房坚 挺。（175）

[A patient said to Dalbiez: "How nice it would be if I were the only who had some organ to penetrate with." Another wished that her breasts were firm.]

The source text states that a masculine lesbian may wish to have a male sexual organ or to have flat and hard breasts like a man. Tao and Li mistranslate the if-clause, again showing problems with their language competence. S/N translate 'rigid' into 'flat', conveying the sense of the source text while Tao and Li literally translate into 'firm'. However, 'firm breasts' by no means implies masculine breasts but those supposed to be beautiful and attractive that many women would wish to have. This to some extent reveals that a male translator can hardly understand how a masculine lesbian may look at her body and 
what kind of body she may wish to have. It is even harder for a male translator to catch what kind of sexual feeling a lesbian seeks in homosexual love. For example,

(8) ST: In the first case their relation often verges upon homosexuality: they sleep together, caress each other, or indulge in breast kisses; the young girl will later seek the same happiness in other arms. (437)

$\mathrm{S} / \mathrm{N}$ : 在前一情形下，她们之间的关系时常接近同性恋爱：她们一同 睡觉, 相互爱抚, 或互吻胸部; 此少女以后将在别的怀抱中寻索同 样的快乐。（186）

[In the former case, their relation is often close to homosexuality: they sleep together, caress each other, or kiss each other's breasts; the young girl will later seek the same happiness in other arms.]

Tao: 第一种情况, 她们的关系接近同性恋: 她们睡在一起, 相互 抚摸, 或很喜欢轻触乳房。少女后来在别人的怀抱里也会有这种快 活。（474）

[In the first case, their relation is close to homosexuality: they sleep together, caress each other, or enjoy very much lightly touching breasts; the young girl will later have the same happiness in other arms.]

Li: 前者之间的关系近乎同性恋, 她们在一起睡觉, 相互爱抚, 或着 [sic]喜欢轻轻地触摸乳房, 这样的少女未来躺在别人怀抱中也会感 到这种快感。(175)

[In the former case their relation is close to homosexuality, they sleep together, caress each other, or enjoy lightly touching breasts; such a young girl will in the future feel the same happiness in other arms.]

This example tells a case of mother-daughter relation similar to homosexuality. What happens between the daughter and mother-caressing each other, or kissing each other's breasts-influences the girl's sexuality in her future life. Since the girl is used to and enjoys the happiness from the caresses and kisses, she will be desirous for these in her future sexuality. Tao and Li translate 'kisses' into 'lightly touching' and 'seek' into 'have' or 'feel' which dramatically dilute the sexual pleasure and the resultant desire in the girl. As men, Tao and Li may not know that, to a woman, lightly touching breasts cannot produce as much sexual pleasure as kissing the breasts.

\section{3. Attitude towards lesbianism}

Besides the issues discussed above, there are signs showing that Tao and $\mathrm{Li}$ may be biased against lesbianism as indicated in the following three examples. 
(9) ST: Though she can employ artificial means for the deflowering and possessing her loved one, she is none the less a castrate [...]. (434)

$\mathrm{S} / \mathrm{N}$ : 但虽然她能运用人造工具翟入而占有她的爱人，她到底缺乏男 性之性能, [...]。（183）

[But although she can use artificial tools to penetrate and possess her lover, she after all lacks masculine sexual function, [...].

Tao: 虽然她能够以人为方式夺取她爱人的贞操并将她占有，但她仍 然是个菴人, [...]。（471）

[Although she can dispossess the virtue of her lover and possess her in an artificial way, she is still a castrated person, [...].

$\mathrm{Li}$ : 然而就算她可以用人为手段夺走她情人的贞操而占有她, 也改变 不了她是个菴人的事实, [...]。（175）

[However even if she can dispossess the virtue of her lover and possess her in an artificial way, she cannot change the fact that she is a castrated person, $[\ldots]$.

The word 'castrate' in the source text refers to the sexual inability of a masculine lesbian to satisfy her lover due to lack of a male sexual organ. The male translators both literally render it into '阉人' [castrated person], a term with strong derogative connotation in Chinese culture. It not only refers to a man who has been castrated and is incapable of reproduction, but also refers to a sexually repressed person. What is more, it often implies that such a man is not a man, or even that such a person is neither man nor woman. It seriously hurts when used against a person, usually a man. It is seldom linked to a woman. The translation by $\mathrm{S} / \mathrm{N}$ simply expresses the fact that a castrate is a person who 'lacks masculine sexual function', avoiding any disparaging connotation the term may have. These two different renditions produce a sharp contrast in the attitudes of the female and male translators towards lesbianism. This happens again in the next two examples.

(10) ST: If she is passive and sensual, she will not be repelled by the caresses of a woman friend, since she will in this case have only to give way and let herself be gratified. If she is active and fiery, she will seem 'androgynous,' $[$...]; (440)

$\mathrm{S} / \mathrm{N}$ : 如果她被动而肉感, 她将不厌恶女朋友的爱抚，因为在此情形 下她只需给出去, 并让自己获得满足。如果她主动而狂热, 她将象 个 “两性人”, [...]。（189）

[If she is passive and sensual, she will not dislike the caresses of a girl friend, because, under such circumstances, she only needs to give away, and let herself be satisfied. If she is active and fanatic, she will seem 'a bisexual person,' [...].] 
Tao: 如果她是被动的、渓荡的, 就不会讨厌女友的抚摸, 因为她这 时只能退却, 让自己得到满足。如果她是主动的、狂热的, 她就会 像个 “阴阳人”似的, [...]。（477）

[If she is passive and immoral, she will not dislike the caresses of a girl friend, because, at this time, she can only fall back, and let herself be satisfied. If she is active and fanatic, she will seem 'an epicene person,' [...].]

Li: (cut) (176)

Here S/N translates 'sensual' and 'androgynous' into '肉感' [sensual] and ‘两 性人' [a bisexual person], which are descriptive terms in Chinese, while Tao translates into '淫荡的' [immoral] and '阴阳人' [an epicene person], both of which contain strong negative connotations and associations in Chinese culture, thereby revealing his attitude towards lesbianism. Tao literally translates 'give way' into 'fall back', which is one of the dictionary meanings of 'give way' but not what the source text means. There is no logic connection between 'fall back' and 'let herself be satisfied'. This once again shows his misunderstanding of the source text. This example is cut in Li's translation, but the next example reveals his similar attitude towards homosexuality.

(11) ST: The truth is that homosexuality is no more a perversion deliberately indulged in than it is a curse of fate. (446)

$\mathrm{S} / \mathrm{N}$ : 事实是, 同性恋爱既非天生之命运, 亦非存心耽溺的变态。 (196)

[The fact is that homosexuality is not an innate fate, nor a deliberate perversion.]

Tao: 实际上, 同性恋既不是一种厄运, 也不是被有意纵情享受的一 种变态, $[\ldots]$ 。 (483)

[In fact, homosexuality is not a misfortune, nor a perversion deliberately indulged in.]

Li: 事实上, 同性恋并非是一种厄运, 更不是故意恣情狂欢的变 态, [...]。 (177)

[In fact, homosexuality is not a misfortune, nor a perversion deliberately indulged in.]

In the source text, 'a curse of fate' reflects social bias against homosexuality which Beauvoir intends to dismiss. S/ $\mathrm{N}$ neutrally translates it into 'an innate fate' which is in line with the meaning of the context. Tao and Li both literally translate it into 'misfortune'. The negative term is faithful to the local expression but retains the social bias toward homosexuality. 


\section{Conclusion}

The above analysis at lexical level shows differences between the female and male translators in their translation strategies, understanding of lesbianism, and attitudes towards lesbianism. In all these differences, gender plays a key role.

In the translations by the male translators, misunderstanding, mistranslation and even patriarchal translation appear from time to time. They may be due to different reasons, such as language competence, gender identity and sexual orientation. The mistranslations often result from their literal or word-for-word translation, a strategy often adopted when a translator is unable to grasp the exact source text meaning. In addition, as heterosexual men, Tao and Li seem hardly able to understand lesbian relations and sexuality. As a result, misunderstandings and mistranslations are inevitable. Moreover, they consciously and unconsciously disclose their bias against homosexuality, which is still taboo and largely unacceptable in China. Their translations reveal a male perspective of looking at lesbianism; there are patriarchal traces, even if they work in women's studies (such as Tao).

In translating the lesbian chapter, the female translators on the whole keep close to the source text and convey what the source text expresses. However, they seem to be more sensitive to issues regarding translating the lesbian relations and sexuality. Beauvoir claims that "all women are naturally homosexual" (1993: 428). If this is true, it should be easier for female translators to understand the lesbian relations and sexuality as they can make use of their own lived experience. More importantly, S/N deviate from the source text at times to remove or lighten the social bias or constraints concerning lesbianism. This is a women-identified approach, reflecting their conscious and unconscious feminism. At least, women tend to instinctively exercise their sympathy when translating works by other women.

This paper is a micro-level examination with limited data of lesbianism in The Second Sex translated into Chinese. This is a part of my larger PhD project, in which the female body, female sexuality and lesbianism are studied both more extensively at the micro-level, but also at the macro-level, concerning institutional and personal censorship of sexual material in the Chinese translations of The Second Sex and The Vagina Monologues.

\section{Acknowledgements}

Special thanks to Dr. James St. André for his invaluable advice on and proofreading for this paper. 


\section{References}

Agorni, Mirella. (2005) "A Marginal(ized) Perspectives on Translation History: Women and Translation in the Eighteenth Century". Meta L:3. pp. 817-830.

Altman, Meryl. (2007) "Simone de Beauvoir and Lesbian Lived Experience". Feminist Studies 33:1. pp. 207-232.

Andone, Oana-Helena. (2002) "Gender Issues in Translation". In: Dollerup, Cay \& Wang Ning (eds.) 2004. Perspectives: Studies in Translatology (2nd volume). pp. 130-145.

Arrojo, Rosemary. (1994) "Fidelity and the Gendered Translation". TTR 7:2. pp. 147-63.

Arrojo, Rosemary. (1995) "Feminist 'Orgasmic' Theories of Translation and their Contradictions". TradTerm 2. pp. 67-75.

BASSNETT, Susan. (1992) "Writing in No Man's Land: Questions of Gender and Translation". Ilha do Desterro 28, $2^{\circ}$ semestre 1992. pp. 63-73.

Baumgarten, Nicole. (2005) "On the Women's Service?: Gender-conscious Languages in Dubbed James Bond Movies". In: Santaemilia, José (ed.) 2005. Gender, Sex and Translation: The Manipulation of Identities. Manchester, UK \& Northampton, USA: St. Jerome Publishing. pp. 53-70.

BEAuvoir, Simone de. (1975) Force of Circumstance. Translated by Richard Howard. Harmondsworth: Penguin.

BEauvoir, Simone de. (1993) The Second Sex. Translated and edited by H.M. Parshley. New York: Knopf.

BIRD, Phyllis A. (1988) "Translating Sexist Language as a Theoretical and Cultural Problem". Union Seminary Quarterly Review 42:1-2. pp. 89-95.

ButLer, Judith. (1999) Gender Trouble: Feminism and the Subversion of Identity. New York \& London: Routledge.

Chamberlain, Lori. (1988) "Gender and the Metaphorics of Translation". Signs 13:3. pp. 445-472.

CHEN, Huan. (2004) "Zhengben qingyuan nvxing shengjing" [Tracing the women's bible back to its origin]. Zhonghua dushubao, August 4th 2004. http:// www.gmw.cn/01ds/2004-08/04/ content_71928.htm. (Accessed on 16 May 2009.)

CHEN, Lin. (2004) "Jin shinian jianada fanyi lilun yanjiu pingjie" [Canadian Translation Theory and Research in the Recent Ten Years]. Chinese Translators Journal 25:2. pp. 68-71.

Cixous, Hélène. (1975) "The Laugh of the Medusa". In: Marks, Elaine \& Isabelle de Courtivron (eds.) 1980. New French Feminisms. Amherst: The University of Massachusetts. pp. 245-264.

CRISAFUlli, Edoardo. (2001) "Dante's 'Shameless Whore': Sexual Imagery in Anglo-American Translations of the Comedy". TTR 14: 1. pp. 11-38. 
DAI, Jinhua. (2007) "Suiye liu heng" [Time leaves trances]. Shu wu [Book Room] 10. pp. 36-41.

Diaz-Diocaretz, Myriam. (1985) Translating Poetic Discourse: Questions on Feminist Strategies in Adrienne Rich. Amsterdam \& Philadelphia: Benjamins.

FuCHS, Jo-Ann P. (1980) "Female Eroticism in The Second Sex". Feminist Studies 6:2. pp. 304-313.

GAO, Juefu. (trans) (1984/2004) Jingshen fenxi yinglun [Introductory Lectures on Psycho-analysis], Sigmund Freud. Beijing: The Commercial Press.

GE, Chuangui, Lu Gusun; Xue Shiqi et al. (eds.) (2000/2002) Xin Yinghan cidian (shiji ban)[A New English-Chinese Dictionary (Century Edition)]. Shanghai: Shanghai Translation Publishing House.

GODARD, Barbara. (1990) "Theorizing Feminist Theory/ Translation". In: Bassnett, Susan \& André Lefevere (eds) 1990. Translation: History and Culture. London: Frances Pinter. pp. 87-96.

GULDIN, Rainer. (2007) "I believe that my two tongues love each other cela ne m'étonnerait pas': Self-Translation and the Construction of Sexual Identity". TTR 20:1. pp. 193-214.

FALLAIzE, Elizabeth. (2002) "Le Destin de la Femme au Foyer: Traduire La Femme Mariée de Simone de Beauvoir". In: Delphy, Christine; Sylvie Chaperon; Kate Fullbrook \& Edward Fullbrook (eds.) 2002. Cinquantenaire du Deuxieme Sexe. Paris: Syllepse.

Flotow, Luise von. (1991) "Feminist Translation: Contexts, Practices, Theories". TTR 4:2. pp. 69-84.

Flotow, Luise von. (1994) “Québec's 'Écriture au féminin' and Translation Politicized”. In: Eguíluz, F. ; R. Merino et al. (eds.) 1994. Transvases Culturales: Literatura, Cine, Traducción. Vitoria, Spain: Facultad de Filologia, Universidad del País Vasco. pp. 219-229.

Flotow, Luise von. (1995a) "Appendix: Beginnings of a European Project: Feminism and Translation Studies". TTR 8:1. pp. 271-277.

Flotow, Luise von. (1995b) "Translating Women of the Eighties: Eroticism, Anger, Ethnicity". In: Simon, Sherry (ed.) 1995. Culture in Transit: Translating the Literature of Quebec. Montreal: Véhicule Press. pp. 31-46.

Flotow, Luise von. (1996a) "Weiblichkeit, Zweisprachigkeit und Übersetzung: Kanada”. In: Strutz, John \& Peter Zima (eds.) 1996. Literarische Polyphonie. Tübingen: Günter Narr. pp. 123-136.

Flotow, Luise von. (1996b) "Legacies of écriture an féminine: Bilingual Transformances, Translation Politicized, Subaltern Versions of the Text of the Street". Journal of Canadian Studies. Spring Issue. pp. 89-109.

Flotow, Luise von. (1997a) Translation and Gender: Translating in the 'Era of Feminism'. Manchester: St Jerome. 
Flotow, Luise von. (1997b) "Mutual Pun-ishment? The Translation of Feminist Wordplay: Mary Daly's Gyn/Ecology in German”. In: Delabastita, Dirk (ed.) 1997. Traductio: Essays on Punning and Translation. Manchester: St. Jerome \& Namur: Presses Universitaires de Namur.

Flotow, Luise von. (1998) "Dis-Unity and Diversity: Feminist Approaches to Translation Studies". In: Bowker, L. et al. (eds.) 1998. Unity in Diversity? Current Trends in Translation Studies. Manchester: St. Jerome. pp. 3-13.

Flotow, Luise von. (2000) "Translation Effects: How Beauvoir Talks About Sex in English". In: Hawthorne, Melanie (ed.) 2000. Contingent Loves. Simone de Beauvoir and Sexuality. Richmond, VA: Virginia University Press. pp. 13-33.

Flotow, Luise von. (2002) "Gender in Translation: The Issues Go on". http:// orees.concordia.ca/numero2/essai/Von\%20Flotow.html. (Accessed on 10 October 2007.)

Flotow, Luise von. (2005) "Tracing the Context of Translation: The Example of Gender”. In: Santaemilia, José (ed.) 2005. pp. 39-51.

Flotow, Luise von. (2006) "Feminism in Translation: the Canadian Factor". Quaderns. Revista de traducció 13. pp. 11-20.

Flotow, Luise von. (2009) "Gender and Sexuality". In: Baker, Mona \& Gabriela Saldanha (eds.) 2009. Routlege Encyclopedia of Translation Studies (2nd edition). London: Routledge. pp. 122-126.

Freiwald, Bina. (1991) "The Problem of Trans-lation: Reading French Feminisms". TTR 4:2. pp. 55-68.

HAMERLAin, Souad. (2005) "Translation as a Transmitter of Feminist Ideology". Annales du Patrimoine 3. pp. 55-58.

HAN, Jiaming. (1996) “Fanyi yanjiu' xuepai de fazhan" [The Development of 'Translation Studies' School]. Chinese Translators Journal 5. pp. 48-50.

Hartman, Kabi. (1999) "Ideology, Identification and the Construction of the Feminine: Le Journal de Marie Bashkirtseff". The Translator 5:1. pp. 61-82.

HARVEY, Keith. (1998) "Translating Camp Talk: Gay Identities and Cultural Transfer". The Translator 4:2. pp. 295-320.

HARVEY, Keith. (2000) "Gay Community, Gay Identity and the Translated Text". TTR 13:1. pp. 137-165.

HARVEY, Keith. (2003) Intercultural Movements: "American Gay" in French Translation. Manchester: St Jerome.

Hawthorne, Melanie C. (2000) "Introduction". In: Hawthorne, Melanie C. (ed.) Contingent Loves. Simone de Beauvoir and Sexuality. Richmond, VA: Virginia University Press. pp. 1-12.

Hellerstein, Kathryn. (2000) "Translating as a Feminist: Reconceiving Anna Margolin". Prooftexts: A journal of Jewish Literary History 20. pp. 191-207.

Henitiuk, Valerie. (1999) "Translating Woman: Reading the Female Through the Male”. Meta XLIV:3. pp. 369-484. 
HUANG, Hong. (2009) 'Ximengna-de·Bofuwa bainian: chongcin faxian haili"Bofuwa jiqi dangdai yiyi" guoji xueshu yantaohui zongshu [Simone de Beauvoir Centennial: Rediscovering Beaver-"Beauvoir and her contemporary significance"]'. Contemporary Foreign Literature 1. pp. 175-176.

HUANG, Lin. (2006) "Zuowei nvxing zhuyi fuhao de linglei changing" [A special side of feminist symbols]. China Book Review 5. pp. 78-84.

HuANG, Lin. (2009) "Di er xing 60 nian ji nvxing zhuyi zai zhongguo" [The Second Sex for sixty years and feminism in China ]. http://blog.sina.com.cn/ huanglinblog. (Accessed on 26 April 2010.)

JiANG, Xiaohua. (2004) "Nvxing zhuyi dui fanyi lilun de yingxiang" [Influence of Feminism upon Translation theory]. Chinese Translators Journal 25:4. pp. 10-15.

KeEnaghan, Eric. (1998) "Jack Spicer's Pricks and Cocksuckers: Translating Homosexuality into Visibility". The Translator 4:2. pp. 273-94.

KINLOCH, David. (2007) "Lilies or Skelfs: Translating Queer Melodrama". The Translator 13:1. pp. 83-103.

KONG HuiYI. (1998) "Wanqing fanyi xiaoshuo zhong de funv xingxiang" [Women's Image in Translated Novels in Late Qing Dynasty]. Comparative Literature in China 2. pp. 71-87.

Krontiris, Tina. (1992) Oppositional Voices: Women as Writers and Translators of Literature in the English Renaissance. London: Routledge.

LARKosH, Christopher. (1996) The Limits of the Translatable Foreign: Fictions of Translation, Migration and Sexuality in 20th Century Argentine Literature. Unpublished Ph.D. dissertation. University of California Berkeley.

LARKOSH, Christopher. (2007) "The Translator's Closet: Editing Sexualities in Argentine Literary Culture”. TTR 20:2. pp. 63-88.

LI, Qiang. (abridged trans) (2004) Di er xing [The Second Sex]. Beijing: Xiyuan chubanshe.

LIAO, Qiyi. (1998) "Kuaxueke zonghe wenhua huigui duoyun hubu—dangdai xifang fanyi lilun zouxiang shiping" [Dimensions of Contemporary of Western Feminist Translation Theory]. Journal of Foreign Languages 5. pp. 26-33.

LindER, Daniel. (2004) "The Censorship of Sex: A Study of Raymond Chandler's The Big Sleep in Franco's Spain”. TTR 17:1. pp. 155-182.

LIN, Shuming. (1999) "Nvxing zhuyi wenxue piping zai dalu de chuanbo" [The spread of feminist literary criticism in China]. Social Science Research 2. pp. 127-132.

LIU, Junping. (2004) "Nvxing zhuyi fanyi lilun yanjiu de zhongzi huayu" [Towards an East-West Discourse on Feminist Translation Studies]. Chinese Translators Journal 25:4. pp. 3-9.

LiU, Kunya. (2009) "Bofuwa di'er xing chuban 60 zhounian: ta bu zai Sate houmian" [The 60th anniversary of the publication of The Second Sex: She is not 
behind Sartre]. Shenzhen wanbao, April 14th 2009. http://book.sina.com.cn/ news/v/2009-04-14 /1139253998.shtml. (Accessed on 16 May 2009.)

LOTBINIĖRE-HARWOOD, Susanne de. (1991) Rebelle et infidèle. La traduction comme pratique de réécriture au féminin/The Body Bilingual. Translation as a Rewriting in the Feminine. Québec: Les éditions du remueménage/The Women's Press.

Lu, Gusun. (chief ed.) (1989/2003) Yinghan da cidian (shang juan) [The EnglishChinese Dictionary (unabridged) (Volume 1)]. Shanghai: Shanghai Translation Publishing House.

LuO, Ting \& Wang Fang. (2004) "Bofuwa zai zhongguo de jieshou yu yingxiang" [The Reception and Influence of Simone de Beauvoir in China]. Contemporary Foreign Literature 4. pp. 123-129.

MAIER, Carol. (1998) "Issues in the Practice of Translating Women's Fiction". BHS LXXV. pp. 95-108.

MAIER, Carol \& Françoise Massardier-Kenney. (1996) "Gender in/and Literary Translation". In: Gaddis Rose, Marilyn (ed.) 1996. Translation Perspectives IX: a Collection of Essays Situating and Proposing New Directions and Major Issues in Translation Studies, Translation Horizons Beyond the Boundaries of Translation Spectrum. Binghampton: State University of New York at Binghampton, Center for Research in Translation. pp. 225-242.

Martín, M. Rosario. (2005) "Gender(ing) Theory: rethinking the Targets of Translation Studies in Parallel with Recent Developments in Feminism". In: Santaemilia, José (ed.) 2005. pp. 27-37.

MASSARDIER-KenNeY, Françoise. (1997) "Towards a Redefinition of Feminist Translation Practice". The Translator 3:1. pp. 55-69.

MoI, Toril. (2002) "While we wait: The English Translation of The Second Sex". Signs 27:4. pp. 1005-1035.

Mu, Lei. (1999) "Xinxian—nv fanyijia Jin Shenghua jiaoshou fangtanlu" [An Interview with female translator and professor Jin Shenghua]. Chinese Translators Journal 2. pp. 36-38.

Mu, Lei. (2002) "Fanyi yu nvxing wenxue: Zhu Hong jiaoshou fangtan lu" [Translation Circles: A Male Cirlces? -An Interview with Hong Kang Female Translator Dr. Kong Huiyi]. Journal of Xi'an Foreign Languages University 10:2. pp. 101-119.

Mu, Lei. (2003) "Fanyi yu nvxing wenxue: Zhu Hong jiaoshou fangtan lu" [Translation and Women's Literature: An Interview with Professor Zhu Hong]. Foreign Languages and Literature 20:1. pp. 41-44.

Mu, Lei et al. (2008) Fanyi yanjiu zhong de xingbie shijiao [Gender Perspective in Translation Studies]. Wuhan: Wuhan University Press.

PORTER, Catherine. (1987) "Translating French Feminism: Luce Irigaray's Ce Sexe qui n'en est pas un". In: Gaddis Rose, Marilyn (ed.) 1987. Translation 
perspectives III, Selected papers, 1985-86. New York: State University of New York, Binghamton. pp. 40-52.

Ríos, Carmen \& Manuela Palacios. (2005) "Translation, Nationalism and Gender Bias”. In: Santaemilia, José (ed.) 2005. pp. 71-80.

RoBINSON, Douglas. (1995) "Theorizing Translation in a Woman's Voice: Subverting the Rhetoric of Patronage, Courtly Love and Morality". The Translator 1:2. pp. 153-175.

SANG, Zhuying \& Nan Shan. (trans) (1986) Di er xing-nvren [The Second SexWomen]. Changsha: Hunan wenyi chubanshe.

SAntaEmilia, José. (2005a) "Researching the Language of Sex: Gender, Discourse and (Im)Politeness". In: Santaemilia, José (ed.) 2005. The Language of Sex: Saying \& Not Saying. Valencia: Universitat de València. pp. 3-22.

SantaEmilia, José. (2005b) "The Translation of Sex, The Sex of Translation: Fanny Hill in Spanish”. In: Santaemilia, José (ed.) 2005. pp. 117-136.

SAntaemilia, José. (ed.) (2005c) Gender, Sex and Translation: The Manipulation of Identities. Manchester, St. Jerome.

SANTAEMiLia, José. (2006) "Researching Sexual Language: Gender, (Im)Politeness and Discursive Construction”. In: Bou, P. (ed.) 2006. Ways into Discourse. Granada: Editorial Comares. pp. 93-115.

Santaemilia, José. (2008a) "Gender, Sex, and Language in Valencia: Attitudes toward Sex-Related Language among Spanish and Catalan Speakers". International Journal of the Sociology of Language 190. pp. 5-26.

SAntaEmilia, José. (2008b) "The Translation of Sex-Related Language: The Danger(s) of Self-Censorship(s)". TTR 21: 2. pp. 221-252.

SHEN, Ke. (2009) "Chongxin renshi Bofuwa-Bofuwa yanjiu xin jinzhan" [Relearning Beauvoir-A review of new developments in Beauvoir studies]. World Literature Recent Developments 3. pp. 45-47.

SHEN, Ke \& Xu Jun. (2009) "Di er xing zai zhongguo de yijie licheng" [The introduction and translation of The Second Sex in China]. Jianghai Academic Journal 4. 199-206.

SHU, Xiaofei. (trans.) (2009) Di er xing [The Second Sex]. Beijing: Xiyuan chubanshe.

SimON, Sherry. (1996) Gender in Translation: Cultural Identity and the Politics of Transmission. London \& New York: Routledge.

SimONS, Margaret A. (1983) "The Silencing of Simone de Beauvoir: Guess What's Missing from The Second Sex". Women's Studies International Forum 6:5. pp. 559-564.

Simons, Margaret A. (1999) Beauvoir and The Second Sex: Feminism, Race, and the Origins of Extentialism. Lanham, Maryland: Rowman \& Littlefield Publishers.

SMITH, Janet S. Shibamoto. (2005) "Translating True Love: Japanese Romance Fiction”. In: Santaemilia, José (ed.) 2005. pp. 97-116. 
SusAm-SARAJEVA, Şebnem. (2005) “A Course on 'Gender and Translation': As an Indicator of Certain Gaps in the Research on the Topic". In: Santaemilia, José (ed.) 2005. pp. 161-176.

TANG, Yi. (trans. \& ed.) (2009) Di er xing: nvren [The Second Sex: Women]. Beijing: Beijing Yanshan chubanshe.

TAO, Tiezhu. (trans.) (1998) Di er xing (quan yi ben) [The Second Sex (translation of the whole book)]. Beijing: Zhongguo shuji chubanshe.

Thompson, Della (chief ed.) \& Chen Kai. (trans) (2003) Niujin xiandai Yinghan shuangjie cidian (xin ban) [Concise Oxford English-Chinese Dictionary) (New Edition)]. Beijing: Foreign Language Teaching and Research Press, Oxford University Press.

WALlMACH, Kim. (2006) "Feminist translation strategies: different or derived?" Journal of Literary Studies, June 1.

WANG, Youqin; Qiu Xichun et al. (trans.) (1988) Nvren shi shenme [What is Woman]. Beijing: Zhongguo wenlian chuban gongsi. http://202.119.83.15:8080/ opac/openlink.php?title=\%C5\%AE\%C8\%CB\%CA\%C7\%CA\%B2\%C3\%B4

WEBER, Orest; Pascal Singy \& Patrice Guex. (2005) "Gender and Interpreting in the Medical Sphere: What is at Stake?" In: Santaemilia, José (ed.) 2005. pp. 137-148.

Wu, Guanghua. (chief ed.) (1993/2002) Hanying da cidian (di er ban) [ChineseEnglish Dictionary (Second edition)]. Shanghai: Shanghai Jiao Tong University Press.

Wu, Guanghua. (chief ed.) (1998) Yinghan keji da cidian [An English-Chinese Dictionary of Science and Technology]. Shanghai: Shanghai Jiao Tong University Press.

XIAO, Yi \& Zhang Yali, et al. (trans.) (1988) Nvxing de mimi [Female Secrets]. Beijing: Zhongguo guoji guangbo chubanshe.

XIE TianzHEN. (1999) Yijie xue [Medio-translatology]. Shanghai: Shanghai Foreign Language Education Press.

XU, Baoqiang \& Yuan Wei. (eds.) (2001) Yuyan yu fanyi de zhengzhi [The Politics of Languages and Translation]. Beijing: Central Compilation $\&$ Translation Press. pp. 309-357.

XU, Lai. (2004) "Zai nvxing de mingyi xia chongxie [Rewriting in the Name of Feminie: The significance of the Feminism Translation Theory in the Study of the Translator's Subjectivity]". Chinese Translators Journal 25:4. pp. 16-19.

ZHANG, Jinghua. (2004) "Nvxing zhuyi dui chuantong yilun de dianfu jiqi juxianxing" [On the Contribution and Limitations of Feminist Translation Theory]. Chinese Translators Journal 25:4. pp. 20-25.

ZHOU, Quan; Yan Zesheng \& Zhao Qianghai. (trans.) (2000/2007) Jingshen fenxi daolun jiangyan [Introductory Lectures on Psychoanalysis], Sigmund Freud. Beijing: International Cultural Publishing Corporation. 